\author{
(online) $=$ ISSN $2285-3642$ \\ ISSN-L = $2285-3642$ \\ Journal of Economic Development, Environment and People \\ Volume 2, Issue 4, 2013 \\ URL: $\underline{\text { http://jedep.spiruharet.ro }}$ \\ e-mail: office jedep@spiruharet.ro
}

\title{
Research on the Core Competitive Power Elements Evaluation System of Green Hotel
}

\author{
Hui LIANG \\ Hubei University of Economics, Wuhan, Hubei, China 430205
}

\begin{abstract}
Green hotel is a new type of hospitality industry development model based on the concept of circular economy and sustainable development. This paper makes an analysis and evaluation of the elements of green hotel core competence, on this basis, constructs the Green Hotel core competitive evaluation index system. The construction of the system is conducive to understand the green hotel's own competitive advantage objectively, and explore ways to enhance its core competitiveness, providing objective basis for sustainable development of China's Hotel industry.
\end{abstract}

Keywords: Green Hotel; Core Competence; Evaluation Index System

\section{JEL Codes: L83}

\section{Introduction}

According to the definition in the Standards for Green Tourist Hotel (LB/T007-2006) released by the National Tourism Administration of PRC on March 23, 2006, green tourist hotel refers to the hotel oriented at the idea of sustainable development, adhering to cleaner production, advocating green consumption, and protecting ecological environment, and its core lies in strengthening the sustainable protection of environment and the reasonable utilization of resources in the course of production and operation. Green tourist hotel is a new concept, requiring hotels to integrate environmental management into hotel business management, give top priority to environmental protection, adjust development strategy, management concept, management mode, and service mode, implement cleaner production, provide products meeting the safe and health requirements of human bodies, and also guide the public to cultivate an awareness in conservation and environmental protection, changes of the traditional consumption concept, and green consumption. Its essence is to provide hotel guests with high quality products meeting the requirements of environmental protection, and realize energy and resources conservation, emission reduction, and environmental pollution prevention, and constantly improve the quality of products [1].

Green hotel core competence theory is needed by the development and maturing of green hotel as a guide, and the ultimate aim of green hotel core competence is to realize customer demands and win customer loyalty, so that market competitive advantages and also excess profit can be won by hotel. Green hotel in China is still in the stage of exploration, and also the application of green technology and the operation and management of hotel far lag behind those in developed countries. It is difficult to enter the 


\author{
(online) $=$ ISSN $2285-3642$ \\ ISSN-L = $2285-3642$ \\ Journal of Economic Development, Environment and People \\ Volume 2, Issue 4, 2013 \\ URL: $\underline{\text { http://jedep.spiruharet.ro }}$ \\ e-mail: office jedep@spiruharet.ro
}

international market because of the insignificant competitive advantages in products and services, so it loses the opportunities to compete with international hotel groups. Therefore, to enhance international competence, it is necessary for green hotel in China to actively meet challenges, provide the vast number of consumers with safe, healthy, and green products from the perspective of protecting the ecological environment according to the requirements of low carbon economy, and promote the harmonious development of man and nature, so that the purpose of breaking green trade barriers and enhancing the international competence can be realized.

\title{
2. The Connotation of Green Hotel Core Competence
}

\subsection{General Review of Enterprise Core Competence}

In 1990, American scholar C. K. Prahalad and British scholar Gary Hamel first proposed the concept of "core competence of enterprise" in their classical essay The Core Competence of the Corporation published in Harvard Business Review. They think that the so-called core competence refers to the knowledge and skills integrated internally by enterprise and especially the integration of those knowledge and skills coordinating all aspects. Along with the proposal of the concept of the core competence of enterprise, core competence quickly becomes a hot point in the studies of enterprise strategic management theory, and its connotation, elements, index system and evaluation method are studied by many scholars successively. Comprehensively, there are three major schools for the general theory for the core competence of enterprise: (1) the "market structure" (also called as environmentalism) represented by Michel E. Porter: it attaches importance to analyzing enterprise competitive advantages from the perspectives of enterprise external industrial structure and enterprise market positioning; (2) the "resource-based view" represented by B. Wernerfelt: it attaches importance to analyzing enterprise competitive advantages from the perspective of enterprise internal resources differences, and thinks that there are differences between enterprises in tangible resources, intangible resources and accumulated knowledge so as to generate enterprise competitive advantages; (3) the "capabilities-based view" represented by C. K. Prahalad and Gary Hamel: it thinks that the core competence of enterprise is an ability system, and the accumulation, maintenance and use of enterprise special ability are the decisive factors of enterprise competitive advantage [2].

Combined with the characteristics of hotel business, Mingzi PU (2008) defined hotel green competence as follows: in the market environment of competition, hotel applies the strategy of sustainable development based o the needs of environmental protection and their own interests, and gains a competitive advantage when rationally allocating hotel resources, providing green hotel rooms and services, and reducing the risks for environment and human health through technology and management innovations [3]. Core competence refers to a "confrontation" ability possessed by enterprise compared with competitors. The core competence of green hotel sources from the competitive advantage of hotel as well as the sustainability and scalability of this advantage, and it can help green hotel to construct enterprise strategy, expand core business, and develop toward collectivization. The core competence of 


\author{
(online) $=$ ISSN $2285-3642$ \\ ISSN-L = $2285-3642$ \\ Journal of Economic Development, Environment and People \\ Volume 2, Issue 4, 2013 \\ URL: $\underline{\text { http://jedep.spiruharet.ro }}$ \\ e-mail: office jedep@spiruharet.ro
}

green hotel consists of four aspects (i.e. green products, human resource management, brand marketing, and corporate culture).

\title{
2.2. The Principles for the Construction of the Green Hotel Core Competence Evaluation Index System
}

The information of all aspects can be expressed by green hotel core competence elements evaluation system in an easy-to-understand way, and thus all sorts of information related to creating enterprise competitive advantages can be provided for hotel managers and also the index system can be used for setting up a goal and monitoring influence results. The index system can help green hotel to design products and make policies. Whatever indexes and how many indexes are chosen for establishing green hotel core competence evaluation index system, the possibility and reliability of data sources are necessarily considered, and a theoretical basis is also necessarily available. In this paper, combined with the actual situation of China, the following principles are mainly followed in the construction of green hotel core competence evaluation index system.

\subsubsection{Necessity}

Different indexes reflect different aspects and content characteristics, and also their function and influence on a specific economic activity are greatly different, so the necessity of core competence influence should be considered in the selection of indexes. That is, the number of the indexes chosen for the contribution of core competence is not large, but the primary and secondary roles of these indexes should be strictly distinguished and properly used, and the indexes directly reflecting enterprise core competence should be highlighted.

\subsubsection{Scientific and operable}

The established index system is necessary to fit hotel macro-environment, industry competition environment, and economic development level. Its calculation method is scientific and easy-to-operate, and also the information can be easy-to-acquire.

\subsubsection{Global and representative}

All designed indexes are required to own a clear definition, not only scientifically reflecting the overall perspective of green hotel core competence, but also integrating the resources of green hotel from the angle of individual elements, so that the core competence of green hotel is excavated and also the important influence of competitive advantage is obtained.

\subsubsection{Comprehensive}

In evaluation, distinct competence and potential competence of green hotel should be fully considered. A multi-index evaluation system is formed through designing multi-dimensional green hotel core competence evaluation elements, and also a multi-index comprehensive evaluation method is used. In the 


\author{
(online) $=$ ISSN $2285-3642$ \\ ISSN-L = 2285-3642 \\ Journal of Economic Development, Environment and People \\ Volume 2, Issue 4, 2013 \\ URL: $\underline{\text { http://jedep.spiruharet.ro }}$ \\ e-mail: office jedep@spiruharet.ro
}

meantime, the characteristics of the combined tangible products and intangible services of hotel are necessarily considered, so as to seek the common factors reflecting and evaluating the core competence of green hotel and also design evaluation indexes from being responsible for environment.

\title{
3. Construction of Green Hotel Core Competence Evaluation Index System
}

In this paper, using the construction method of enterprise competence evaluation index system for reference and according to the roles played by hotel core competence theory as well as all elements in highlighting the competitive advantage of green hotel, the logical framework of green hotel core competence evaluation index system is constructed as shown in figure 1, aiming at guiding green hotel to seize opportunities and integrate enterprise internal and external resources and give full play to their own advantages. Thus, the collaborative and sustainable developments of green hotel core competence elements are realized.

From the logical framework of green hotel core competence evaluation index system, it is known that green hotel core competence evaluation indexes are composed by three layers, which are the layer of environmental elements, the layer of competence elements, and the layer of support elements, respectively.

\subsection{The layer of environmental elements}

Environmental elements are supports highlighting green hotel core competence; a small ecological system internally and externally interacted is formed by hotel and consists of hotel people (including employees and customers), microbial environment, animal and plant environment, climate factors, and energy factors. In this ecological system, hotel people will generate certain food consumption, material consumption, resource consumption and energy consumption, and these consumptions take up a large proportion in the overall energy consumption of the hotel ecological system; there are effects from microbes on hotel indoor environment quality and hotel people's safety and health; there are effects from plants and animals on hotel production and services and hotel people's safety, health and mental state; there are effects from climate factors on hotel business operation; there are effects from energy factors on hotel energy supply cost and environmental benefits.

\subsection{The layer of competence elements}

The layer of competence elements is to create the key point of green hotel core competence, and mainly includes green hotel products, human resource management, brand marketing, and corporate culture. The four elements occupy a key position in the green hotel core competence evaluation index system; the realization of cooperatively integrated hardware and software of green hotel products, the cooperative creation of human resources management, the cooperative promotion of brand marketing, and the powerful propulsion of corporate culture are the key steps of improving green hotel core competence. 


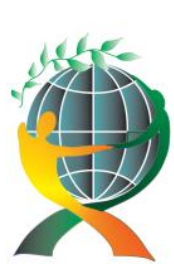

\author{
(online) $=$ ISSN $2285-3642$ \\ ISSN-L = $2285-3642$ \\ Journal of Economic Development, Environment and People \\ Volume 2, Issue 4, 2013
}

URL: http://jedep.spiruharet.ro

e-mail: office jedep@spiruharet.ro

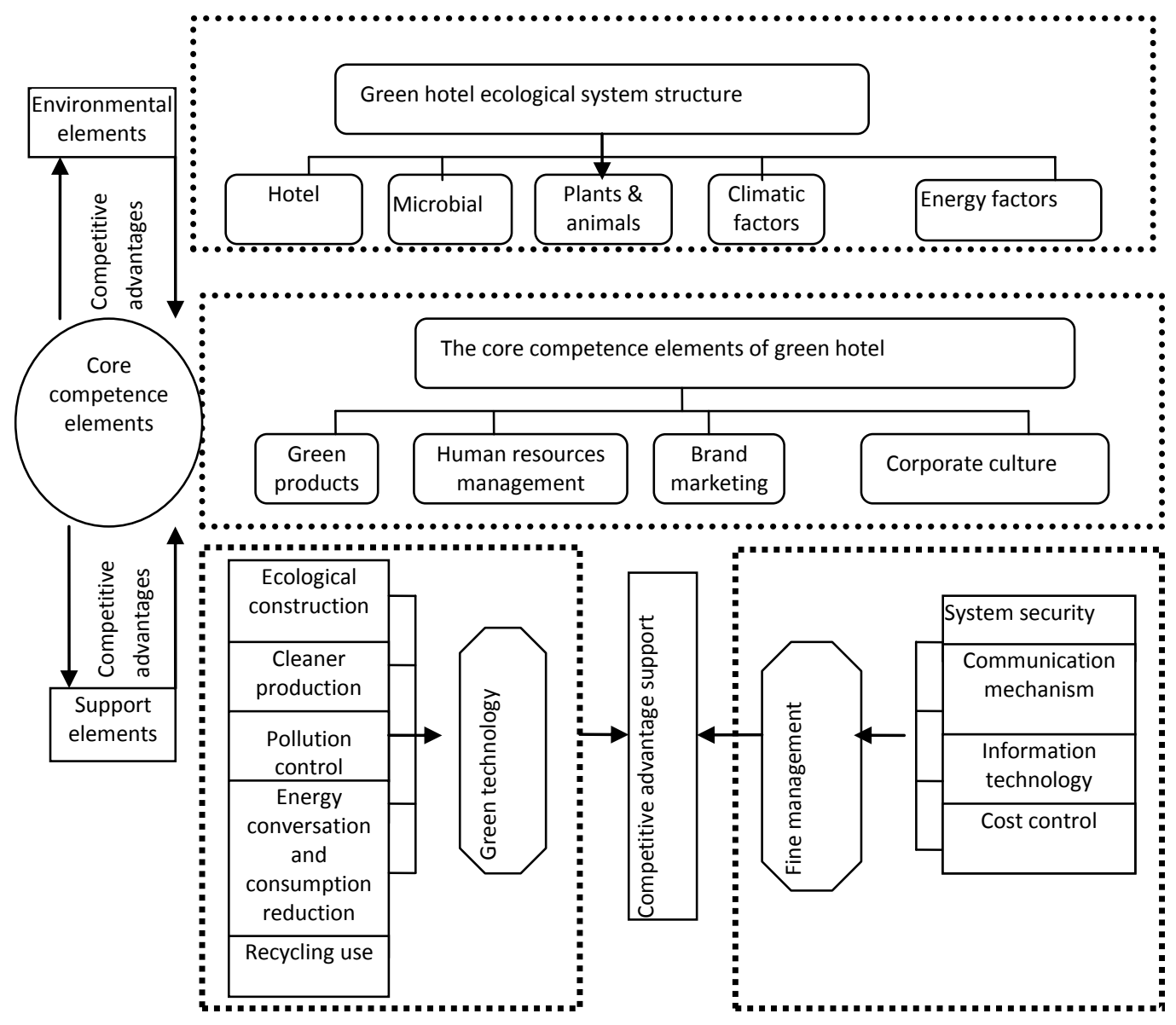

Fig 1: Logical framework of Green hotel core competence evaluation index system

\title{
3.3. The layer of support elements
}

The layer of support elements is a breakthrough point of promoting green hotel the core competence, and mainly includes green technology and fine management. Green technology includes five elements (ecological construction, clean production, pollution control, energy conservation and consumption reduction, and recycling use); ecological architecture embodies the future development direction of green hotel buildings; cleaner production is a production way used by green hotel to protect environment; pollution control shows the responsible attitude of hotel toward external ecological environment; energy conservation and consumption reduction are important means used by green hotel to realize sustainable development; recycling use decides the comprehensive effect of the green technology used by green hotel. 


\author{
(online) = ISSN $2285-3642$ \\ ISSN-L = 2285 - 3642 \\ Journal of Economic Development, Environment and People \\ Volume 2, Issue 4, 2013 \\ URL: http://jedep.spiruharet.ro \\ e-mail: office jedep@spiruharet.ro
}

\title{
4. Evaluation Method
}

In this paper, based on the logical framework of green hotel core competence evaluation index system, the green hotel core competence evaluation index system is divided into four layers (goal layer, sub-goal layer, core indexes, and index variables). Goal layer is to construct the ultimate goal of this system-create the core competence of green hotel; sub-goal layer consists of three sub-goals, which are environmental element, competence element, and support element; core indexes include seven indexes (green hotel ecological system, green hotel products, human resource management, brand marketing, corporate culture, green technology, and fine management); index variables include 30 specific index variables. The dominance relationship among all layers from top to bottom constitutes a hierarchical structure, as shown in table 1.

Table 1: The core competence evaluation index system of Green hotel

\begin{tabular}{|c|c|c|c|c|c|c|}
\hline Goallayer & $\begin{array}{c}\text { Sub-goal } \\
\text { layer }\end{array}$ & No. (S) & Coreindexes & No. (G) & Indexvariables & No. $(P)$ \\
\hline \multirow{7}{*}{ 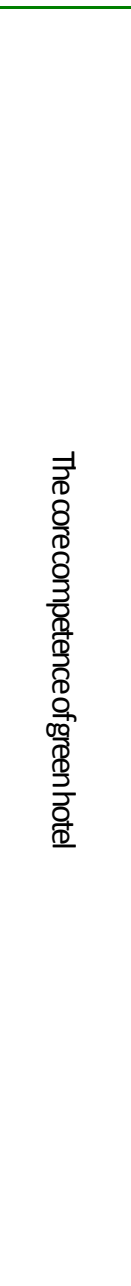 } & 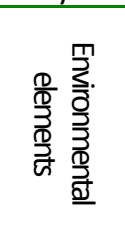 & S1 & $\begin{array}{l}\text { Green hotel } \\
\text { ecological } \\
\text { system }\end{array}$ & G1 & $\begin{array}{c}\text { Hotel people } \\
\text { (Employeesand customers) } \\
\text { Microbial } \\
\text { Plants \& animals } \\
\text { Climate } \\
\text { Energy }\end{array}$ & $\begin{array}{l}\text { P1 } \\
\text { P2 } \\
\text { P3 } \\
\text { P4 } \\
\text { P5 }\end{array}$ \\
\hline & \multirow{4}{*}{ 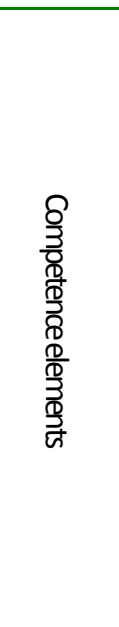 } & \multirow{4}{*}{ S2 } & $\begin{array}{l}\text { Greenhotel } \\
\text { products }\end{array}$ & G2 & $\begin{array}{l}\text { Product characteristics } \\
\text { Product innovation } \\
\text { Senvicequality } \\
\text { Senvice facilities }\end{array}$ & $\begin{array}{l}\text { P6 } \\
\text { P7 } \\
\text { P8 } \\
\text { P9 }\end{array}$ \\
\hline & & & $\begin{array}{c}\text { Human } \\
\text { resources } \\
\text { management }\end{array}$ & G3 & $\begin{array}{l}\text { Employeedrain rate } \\
\text { Employeequality } \\
\text { Training intensity }\end{array}$ & $\begin{array}{l}\mathrm{P} 10 \\
\mathrm{P} 11 \\
\mathrm{P} 12\end{array}$ \\
\hline & & & $\begin{array}{c}\text { Brand } \\
\text { marketing }\end{array}$ & G4 & $\begin{array}{c}\text { Recognition } \\
\text { Popularity } \\
\text { Reputation } \\
\text { Customer satisfaction } \\
\text { Customer loyalty }\end{array}$ & $\begin{array}{l}\text { P13 } \\
\text { P14 } \\
\text { P15 } \\
\text { P16 } \\
\text { P17 }\end{array}$ \\
\hline & & & $\begin{array}{l}\text { Corporate } \\
\text { culture }\end{array}$ & G5 & $\begin{array}{l}\text { Corporate image } \\
\text { Spiritual culture } \\
\text { Incentivemechanism } \\
\text { Staffcohesion }\end{array}$ & $\begin{array}{l}\text { P18 } \\
\text { P19 } \\
\text { P20 } \\
\text { P21 }\end{array}$ \\
\hline & \multirow{2}{*}{ 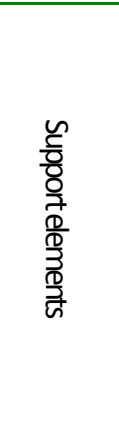 } & \multirow[t]{2}{*}{ S3 } & $\begin{array}{c}\text { Green } \\
\text { technology }\end{array}$ & G6 & $\begin{array}{l}\text { Ecological construction } \\
\text { Cleaner production } \\
\text { Pollution control } \\
\text { Energyconversation and } \\
\text { consumption reduction } \\
\text { Recyclinguse }\end{array}$ & $\begin{array}{l}\text { P22 } \\
P 23 \\
P 24 \\
P 25 \\
P 26\end{array}$ \\
\hline & & & $\begin{array}{c}\text { Fine } \\
\text { management }\end{array}$ & G7 & $\begin{array}{l}\text { System security } \\
\text { Communication } \\
\text { mechanism } \\
\text { Informationtechnology } \\
\text { Costcontrol }\end{array}$ & $\begin{array}{l}\text { P27 } \\
\text { P28 } \\
\text { P29 } \\
\text { P30 }\end{array}$ \\
\hline
\end{tabular}




\author{
(online) $=$ ISSN $2285-3642$ \\ ISSN-L = 2285 - 3642 \\ Journal of Economic Development, Environment and People \\ Volume 2, Issue 4, 2013 \\ URL: http://jedep.spiruharet.ro \\ e-mail: office jedep@spiruharet.ro
}

Green hotel core competence evaluation index system involves many factors and layers so it is very complicated, and also many of its factors are uneasy to quantify and difficult to process with general quantitative or qualitative methods. In this paper, an evaluation model is established by combining fuzzy comprehensive evaluation with analytic hierarchy process, so as to evaluate the core competence of green hotel. The specific steps are as follows:

4.1 Establishing a set of evaluation indexes: The set composed by the sub-goals of green hotel core competence evaluation index system is $C_{S}=\left\{\begin{array}{lll}C_{1} & C_{2}, C_{3}\end{array}\right\}$, and the indexes set composed by core goals is $C_{\mathrm{G}}=\left\{C_{\mathrm{G} 1}, C_{\mathrm{G} 2}, \ldots, C_{\mathrm{Gn}}\right\}$, in which $\mathrm{n}$ is the number of the core indexes in the sub-goal layer.

4.2 Dividing evaluation levels and establishing evaluation standards set: Based on related literature references, consulting experts and the actual conditions of China's green hotel operation, evaluation levels are set as $U=\{$ very good, good, average, poor, very poor $\}$.

4.3 Establishing scores matrix: Scores are provided for evaluation levels (see table 2), and also the scores matrix $H=\{100,85,65,40,25\}$ is established.

4.4 Determining the indexes weight and weight coefficients ( $A$ and ${ }^{A_{i}}$ ) using analytic hierarchy process: The specific steps are as follows:

4.4.1 Green hotel core competence evaluation index judgment matrix is established according to table 1. The indexes of each layer are compared by green hotel rating experts in pairs for obtaining a corresponding judgment matrix. According to the actual conditions of innovative enterprise and the suggestions from experts, pair-wise judgment matrix is constructed with nine-scale method (see table 2).

Table 2: Meaning and value of judgment matrix scales

\begin{tabular}{cc}
\hline Scale & Meaning \\
\hline 1 & Two factors are equally important \\
3 & The first actor is slightly important than the second factor \\
5 & The first actor is strongly important than the second factor \\
7 & The first actor is extremely important than the second factor \\
9 & The value between the above adjacent two cases \\
$2 / 4 / 6 / 8$ & Meaning the opposite \\
Reciprocal & \\
\hline
\end{tabular}

4.4.2 Calculating the maximum feature value of judgment matrix $\lambda$ max and its corresponding feature vector

4.4.3 Implementing a consistency check on judgment matrix scales: $C R=\frac{C I}{R I}$ is calculated, in which $C I=\frac{\lambda \max -n}{n-1}$, and $R I$ is defined as random consistency index and required to pass the consistency 


\author{
(online) $=$ ISSN $2285-3642$ \\ ISSN-L = 2285 - 3642 \\ Journal of Economic Development, Environment and People \\ Volume 2, Issue 4, 2013 \\ URL: http://jedep.spiruharet.ro \\ e-mail: office jedep@spiruharet.ro
}

check because this inconsistent degree has to be controlled within a certain range, so as to prevent the emergence of the consistency in the multi-order judgment. Then, the average random consistency index scale and its coefficient table are introduced, $\mathrm{n}$ is set as judgment matrix order number, and the corresponding average random consistency index is as follows if $n=1,2, \ldots 9$ (see table 3).

Table 3: The values of random consistency index RI

\begin{tabular}{cccccccccc}
\hline $\begin{array}{c}\text { Order number } \\
(\mathrm{n})\end{array}$ & 1 & 2 & 3 & 4 & 5 & 6 & 7 & 8 & 9 \\
\hline $\mathrm{Rl}$ & 0 & 0 & 0.58 & 0.90 & 1.12 & 1.24 & 1.32 & 1.41 & 1.45 \\
\hline
\end{tabular}

If the value of $C R$ is less than 0.10 , judgment matrix consistency can be accepted. Otherwise, the calculation returns to 4.1 for adjusting judgment matrix.

After the relative importance of the elements of each level to the last level, the overall comprehensive importance of the elements in each level to the evaluation system can be solved from top to bottom. After the comprehensive importance is solved, the whole green hotel core competence evaluation index system is completed. Then, the core competence of green hotel can be comprehensively scored through the application of this system.

4.5 Implementing single-factor evaluation: The single-factor evaluation matrix $R i\left({ }^{\mathrm{r}_{i j}}\right)$ from $\mathrm{C}$ to $\mathrm{U}$ is established with Delphi method. The result of single-factor evaluation is $B i=A i \times R i$.

$$
\begin{gathered}
\mathrm{r}_{\mathrm{ij}}=\frac{\text { Choose the number of green hotel rating experts of a factor evaluation result in } \mathrm{U}}{\text { The total number of green hotel rating experts }} \\
R_{\mathrm{i}}=\left[\begin{array}{cccc}
\mathrm{ri}_{11} & \mathrm{ri}_{12} & \cdots & \mathrm{ri}_{1 \mathrm{n}} \\
\mathrm{ri}_{21} & \mathrm{ri}_{22} & \cdots & \mathrm{ri}_{2 \mathrm{n}} \\
\vdots & \vdots & \vdots & \vdots \\
\mathrm{ri}_{\mathrm{m} 1} & \mathrm{ri}_{\mathrm{m} 2} & \cdots & \mathrm{ri}_{\mathrm{mn}}
\end{array}\right]
\end{gathered}
$$

4.6 Fuzzy comprehensive evaluation: Matrix $\mathrm{R}$ is composed by $\mathrm{Bi}$, and then comprehensive matrix $\mathrm{B}$ is solved, namely

$$
\begin{aligned}
& R=\left[\begin{array}{c}
B_{1} \\
B_{2} \\
\vdots \\
B_{i}
\end{array}\right] \\
& B=A \times R
\end{aligned}
$$

4.7 Calculating the comprehensive evaluation value: Each index variable is calculated with $E=B \times H^{T}$. 


\author{
(online) $=$ ISSN $2285-3642$ \\ ISSN-L = 2285-3642 \\ Journal of Economic Development, Environment and People \\ Volume 2, Issue 4, 2013 \\ URL: $\underline{\text { http://jedep.spiruharet.ro }}$ \\ e-mail: office jedep@spiruharet.ro
}

\title{
5. Conclusion and Prospect
}

In this paper, according to the connotation of green hotel and the enterprise core competence theory, the logical framework of green hotel core competence evaluation index system is constructed, and also a concrete evaluation method is given, so that the conclusion in the following is obtained.

First, the preliminary construction of green hotel core competence evaluation index system is helpful for solving many problems in current green hotel investment project evaluation realities, so that the green hotels in China can not only better adapt to the market environment and its change in the new period, and also can harmoniously co-exist with social and ecological environments. Thus, a solid foundation is laid for the long-term development and continuous profitability of green hotel investment projects.

Second, the green hotel core competence evaluation index system constructed in this paper provides evaluation and decision references for tourism management departments to make industry standards, promotes the transformation and upgrading of the hotel industry in China, and also further enriches and improves the core competence theory of service enterprises.

Third, the application of green hotel core competence evaluation index system is helpful for making green hotel strategic development plans. In making green hotel strategic development plans, the green hotel core competence evaluation index system should be applied in combination with the actual conditions, and the staff suggestions and actual conditions of hotel should be fully reflected, so as to guide green hotels in making strategic development plans.

Fourth, in the green hotel core competence evaluation index system constructed in this paper, green idea is deeply rooted in the dimensions of organizational culture and management concept, and also the core competence of green hotel is standardized and refined from hotel argumentation and design to hotel operation and management, so as to tightly focus the win-win goal of environmental benefit and economic benefit.

Green hotel core competence evaluation index system covers all important parts of green hotel operation environment, and more comprehensive core indexes and index variables are chosen than before in it. However, there are still many shortcomings of this study because of the limitations of the subjective and objective conditions. If the longer-term data of green hotel can be tracked and acquired, the core competence elements of green hotel can be further induced and refined with the indexes in this paper. Subsequently, references can be provided for green hotel investors to make harmonious ecological, social and economic development decisions in advance. 


\author{
(online) $=$ ISSN $2285-3642$ \\ ISSN-L = 2285 - 3642 \\ Journal of Economic Development, Environment and People \\ Volume 2, Issue 4, 2013 \\ URL: http://jedep.spiruharet.ro \\ e-mail: office jedep@spiruharet.ro
}

\title{
6. References
}

[1] The National Tourism Administration of the People's Republic of China. Standards for Green Tourist Hotel (LB/T007-2006) [Z]. 2006-03-23.

[2] Guozhen Feng. Research on the Retail Enterprise Core Competitiveness Evaluation Index System based on the Financial Perspective [J]. Enterprise Economy, 2011 (10):100-101.

[3] Mingzi Pu, Fang Xie. An Exploration of Key Factors and Improving Means of Hotel Green Competitive Power [J]. Environmental Engineering, 2008 (26): 334-338.

[4] Muchun Li, Wei Wei. Research on Chinese Hospitality Industry Transition and Upgrading Strategy Based on LowCarbon Technology Innovation [J]. Ecological Economy, 2012 (4):88-89.

[5] Hui Liang, Yuankun Wang. Cultivation and Improvement of the Core Competitiveness of China's Green HotelsShanghai Xinjinjiang Hotel Is Taken as an Example [J]. Productivity Research, 2012 (10):211-212.

[6] Hong Xu. Study on the Core Competitiveness of Hotel Enterprises [M]. Beijing: Tourism Education Press, 2004.

[7] Xing Gao. Green Hotel Economic Development and Operation and Management Modes [M]. Beijing: China Building Industry Press, 2010.

[8] Peng Ma, Tianyou Wang, Wei Zhang. The Construction of the Knowledge Management Evaluation Index System Oriented at Enterprise Core Competitiveness-the Hotel Industry Is Taken as an Example [J]. Science and Technology Management Research, 2008 (6). 